\title{
VALIDATING AN INTEGRATED DECISION-SUPPORT FRAMEWORK FOR ROAD TRANSPORTATION IN GAUTENG, SOUTH AFRICA
}

\author{
GEORG HEINRICH (HEINI) BACKEBERG \\ heinib@telkomsa.net \\ Department of Transport and Supply Chain Management \\ University of Johannesburg
}

\begin{abstract}
The South African government has committed itself to creating "a better life for all". Furthermore, government performance became important for the South African government with the introduction of the Public Finance Management Act. Backeberg (2005) uses systems thinking to propose a holistic transportation performance quantification framework to achieve the above. The purpose of this research is to validate the above framework by demonstrating its practicality and usefulness. This is done by populating the framework with representative transportation statistics from various sources. The study demonstrates how improvements could be prioritised if adequate information were to be available.
\end{abstract}

\section{INTRODUCTION}

The ultimate aim of government can be derived from a statement by the Gauteng Department of Public Transport, Roads and Works (2002: 8) that refers to the aim as "continuous transformation or improvement to create a better life for all". In support of this statement, the main aim or purpose of transportation can be derived from the stated vision and mission of the Gauteng Department of Public Transport, Roads and Works (2003b: 5) as follows: "To cost-effectively facilitate an integrated transport system that promotes accessibility and the safe and affordable movement of people, goods and services". Six goals or applications can be identified, namely road safety, road infrastructure, traffic, public transport, freight and non-motorised transport (Backeberg, 2005: 26-27).

\section{PROBLEM STATEMENT AND SCOPE OF THE RESEARCH}

For a decision-support system to be effective, the following is needed:

(a) a way of identifying performance indicators and quantifying them

(b) a system that captures the necessary data, processes it and presents the information in a way that will facilitate decision-making

(c) a way of managing and maintaining the above system. This does not form part of the research. 
Point (a) above is addressed by Backeberg (2005). He explains the problem of fractured information elements for policy-making and applies systems thinking to develop an integrated cost-effectiveness framework for improving policy/decision-making at top level. His model displays the direct government expenditure (on each of the six applications) on the one side and the resulting economic benefits (or costs) of each on the other. $\mathrm{He}$ suggests indicators, quantifiers and multipliers to quantify the latter, but does not elaborate on these. Detail of (a) above will not be repeated in this study.

A model of (b) above is described in an article (by the same author) elsewhere in this publication, which will not be repeated here. The model is however not validated and the value of this data, if available, may not be evident to the reader. The latter is the focus of this research: the purpose of this study is therefore to validate the model by populating it with typical transportation data, in order to demonstrate the importance (and value) of such an integrated transportation information system. Detail of the data sources and the process of obtaining the data falls outside the scope of this study.

Although the principles apply equally well to air, sea and rail transport, for simplicity only road transport is addressed in the research. In the context of the research the term "transportation" therefore refers to "road transportation" in the narrower sense. It should also be cautioned that the statistical information provided, although being representative, is neither intended to be accurate nor all-inclusive.

For further simplification, only three of the six transportation applications listed earlier are quantified, namely road safety, traffic and road infrastructure. This will demonstrate the significance of determining the total performance of transportation in Gauteng, indicating how it can enable decision-makers to prioritise their actions and thereby optimally contribute towards a better life for all.

\section{DEMONSTRATING THE PROPOSED DECISION-SUPPORT SYSTEM BY QUANTIFYING THE PERFORMANCE OF THREE GOALS IN THE PURPOSE STRUCTURE BY MEANS OF THE COST-EFFECTIVENESS MODEL}

\section{Introduction}

As mentioned earlier, three transportation applications or goals will be addressed for the purpose of the demonstration, namely road safety, road traffic (especially congestion) and road infrastructure. These three applications will be quantified with representative data to demonstrate the model. For each application four categories have to be estimated from external sources, namely: 
1 the allocated expenses (in this case by the Gauteng Provincial Government)

2 the value of each indicator

3 a benchmark for each indicator

4 a multiplier for each indicator.

In each case, the economic cost is calculated as follows:

Economic cost $=(B-C) \times D$

Statistics from various data sources are used. As the Gauteng Provincial Government (represented by the Transport Branch in the Gauteng Department of Public Transport, Roads and Works) is used as a case study, information will be applied only to those provincial roads under the jurisdiction of the above institution. This will enable comparison of provincial expenses (the cost side - excluding the national government and local authorities) with performance results obtained. Where performance information is only available on provincial (including the national government and local authorities) or national scale, approximations will be made by proportioning the figures to known relationships, such as the length of roads under provincial jurisdiction relative to the total length of roads in Gauteng. Similar approximations are made in the number split between the various categories of accidents, such as fatal, serious injury, light injury and damage only.

It will be shown that the model makes it possible to obtain an estimate of the ultimate contribution of transportation to a better life for all.

\section{Assumptions}

Table I lists the assumptions and information sources that were used to populate the model.

Table I: List of assumptions and sources for populating the model

\begin{tabular}{|c|c|c|c|}
\hline No & Description & Value & Source/Reasoning \\
\hline A & Heavy rehabilitation & R1.40 million per km & Africon 2005 JV 7 Jul \\
\hline $\mathrm{B}$ & Light rehabilitation & R0.75 million per km & Africon 2005 JV 7 Jul \\
\hline $\mathrm{C}$ & New paved road rural & R7 million per km & Africon 2005 JV 7 Jul \\
\hline $\mathrm{D}$ & New paved road metro & R10 million per km & Africon 2005 JV 7 Jul \\
\hline$E$ & Interchange & R50 million per km & Africon 2005 JV 7 Jul \\
\hline $\mathrm{F}$ & Added vehicle cost to bad roads & R 0.50 per vehicle-km & $50 \%$ of value in Africon 2005 JV 7 Jul \\
\hline G & Annual percentage increase in traffic & $5 \%$ p.a. & Africon 2003 \\
\hline $\mathrm{H}$ & Total provincial roads & 4888 km & $\begin{array}{l}\text { Gauteng Department of Public } \\
\text { Transport, Roads and Works, 2003a: } 3.8\end{array}$ \\
\hline I & $\begin{array}{l}\text { Live vehicle population Gauteng } \\
1998\end{array}$ & 2450240 vehicles & $\begin{array}{l}\text { National Department of Transport } \\
\text { 2001:Table 2.3.1 }\end{array}$ \\
\hline
\end{tabular}




\begin{tabular}{|c|c|c|c|}
\hline $\mathrm{J}$ & $\begin{array}{l}\text { Live vehicle-population South } \\
\text { Africa } 1998\end{array}$ & 6603578 vehicles & $\begin{array}{l}\text { National Department of Transport } \\
\text { 2001:Table 2.3.1 }\end{array}$ \\
\hline K & Vehicle km South Africa 1998 & $\begin{array}{l}130137 \text { million per } \\
\text { vehicle-km }\end{array}$ & $\begin{array}{l}\text { National Department of Transport } \\
\text { 2001:Table 2.4.12 }\end{array}$ \\
\hline $\mathrm{L}$ & Value of time & R60 & Africon 2003 \\
\hline M & Fuel cost & R0.50 & $\mathrm{R} 5 / \mathrm{l}$ at $10 \mathrm{l} / 100 \mathrm{~km}$ \\
\hline $\mathrm{N}$ & Trips per day on Ben Schoeman & 100000 trips & Africon 2003 \\
\hline $\mathrm{O}$ & Average travel distance & $30 \mathrm{~km}$ & Africon 2003 \\
\hline$P$ & Average trip time & 0.5 hours & Africon 2003 \\
\hline Q & Work days per year & 250 days & Africon 2003 \\
\hline $\mathrm{R}$ & $\begin{array}{l}\text { Percentage Gauteng provincial } \\
\text { roads bad and very bad }\end{array}$ & $25 \%$ & $\begin{array}{l}\text { Gauteng Department of Public } \\
\text { Transport, Roads and Works, } 2001 . \\
\text { Annual Report 2000/1 }\end{array}$ \\
\hline $\mathrm{S}$ & $\begin{array}{l}\text { Annual percentage increase in } \\
\text { bad to very bad roads }\end{array}$ & $2 \%$ & $\begin{array}{l}\text { Gauteng Department of Public } \\
\text { Transport, Roads and Works, } 2001 . \\
\text { Annual Report 2000/1 }\end{array}$ \\
\hline $\mathrm{T}$ & $\begin{array}{l}\text { Percentage of road network } \\
\text { experiencing congestion }\end{array}$ & $23 \%$ & $\begin{array}{l}\text { Gauteng Department of Public } \\
\text { Transport, Roads and Works, } 2001 . \\
\text { Annual Report 2000/1 }\end{array}$ \\
\hline$U$ & $\begin{array}{l}\text { Percentage vehicle } \mathrm{km} \text { travelled in } \\
\text { peak hours }\end{array}$ & $50 \%$ & Estimate derived from own experience \\
\hline V & $\begin{array}{l}\text { Average percentage trip time } \\
\text { added at congested road elements }\end{array}$ & $20 \%$ & Estimate derived from own experience \\
\hline W & $\begin{array}{l}\text { Average percentage fuel costs } \\
\text { added at congested road elements }\end{array}$ & $20 \%$ & $\begin{array}{l}\text { Estimate derived from own experience } \\
- \text { includes detours to avoid congestion }\end{array}$ \\
\hline$x$ & $\begin{array}{l}\text { Added maintenance cost due to } \\
\text { bad roads }\end{array}$ & R0.70 million per km & $A-B$ rounded \\
\hline Y & Pro rated vehicle km Gauteng 1998 & $\begin{array}{l}48287 \text { million } \\
\text { vehicle-km }\end{array}$ & $K \times I \div J$ \\
\hline Z & Average vehicle speed & $60 \mathrm{~km} / \mathrm{h}$ & $\mathrm{O} / \mathrm{P}$ \\
\hline Za & Total roads in Gauteng & $34100 \mathrm{~km}$ & $\begin{array}{l}\text { Gauteng Department of Public } \\
\text { Transport, Roads and Works, 2003a: } 3.8\end{array}$ \\
\hline $\mathrm{Zb}$ & $\begin{array}{l}\text { Pro rated vehicle km Gauteng } \\
\text { Provincial Roads } 1998\end{array}$ & 6922 vehicle-km & $\mathrm{Y} \times \mathrm{H} \div \mathrm{Za}$ \\
\hline Zc & $\begin{array}{l}\text { Benchmark fatalities per } 100 \\
\text { million vehicle-km }\end{array}$ & $\begin{array}{l}3 \text { fatalities } / 100 \text { million } \\
\mathrm{km}\end{array}$ & Katz, D. 2005 \\
\hline
\end{tabular}

The values in Table I are self-explanatory, and will be used in the analysis to follow. 


\section{Cost-effectiveness model applied to road safety on Gauteng provincial roads}

The result is shown in Figure 1.

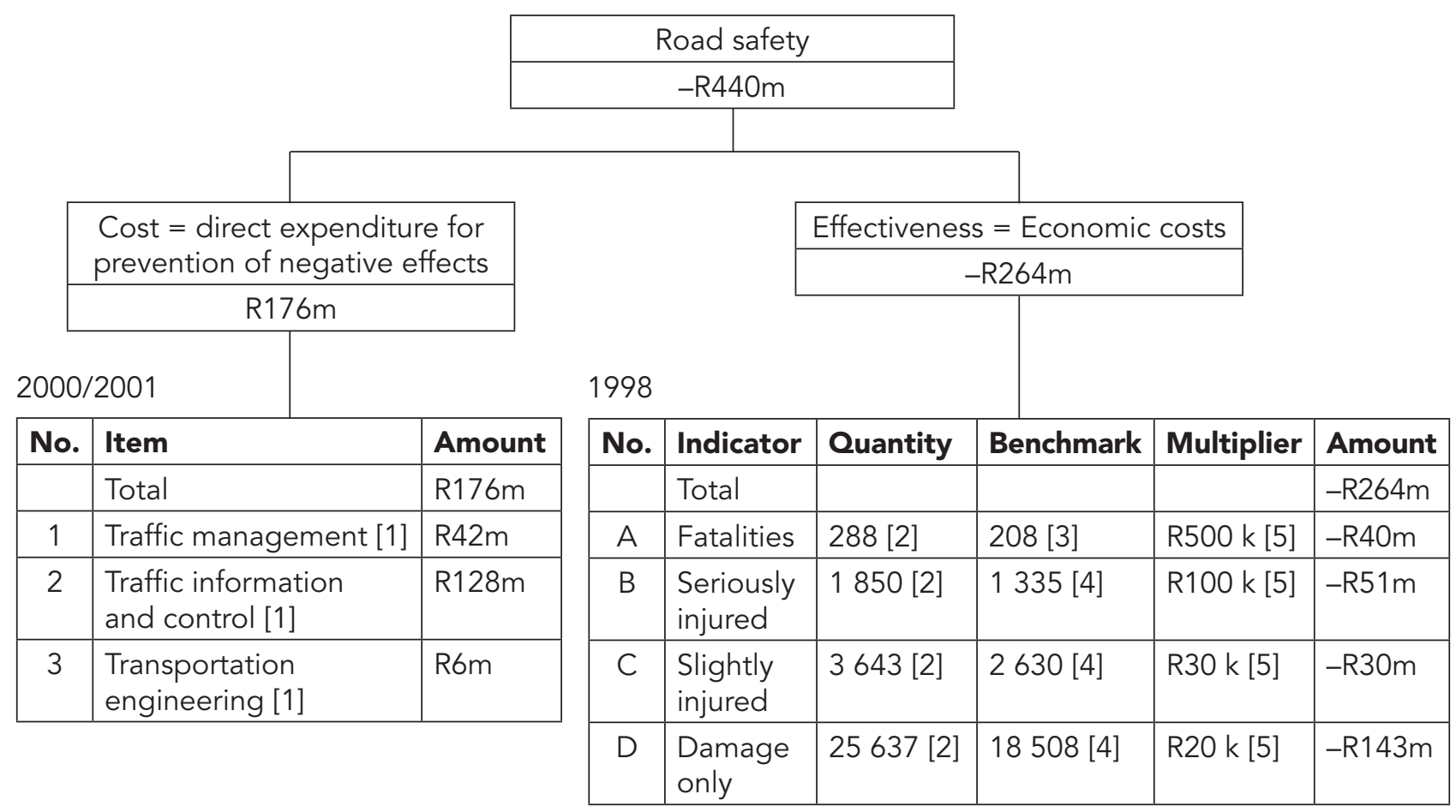

\section{Notes to Figure 1 (numbers in square brackets refer to notes below):}

General note: Letter $m$ and $k$ after a number implies million and thousand respectively.

Note 1: Includes law enforcement (Gauteng Department of Public Transport, Roads and Works 2003b: 62-63).

Note 2: Values calculated as follows: [values from CSIR, 2002] $\times[H \div Z a$ in Table 1].

Note 3: Values calculated as follows: $(\mathrm{Zb} \times \mathrm{Zc}) \div 100$ in Table 1 .

Note 4: Proportioned to fatalities.

Note 5: CSIR, 2000, as quoted by Africon, 2003.

Figure 1: Cost-effectiveness model applied to road safety on

Gauteng provincial roads (for demonstration only)

Figure 1 shows that accident prevention cost the Gauteng Transport Branch R176 million, resulting in further costs to the Gauteng economy of R264 million because of the accident rate, totalling R440 million. This figure is highly dependent on the assumptions with regards to benchmarks and multipliers.

In Figure 1, the benchmark for fatalities was derived from fatality statistics in the USA (Katz, 2005). The other three benchmarks were proportioned to the fatality ratio between South Africa and the USA. The multipliers were derived from a CSIR-report (CSIR, 2000, as quoted by Africon, 2003). The rest of the table is self-explanatory. According to the above assumptions the total cost-effectiveness figure for road safety on Gauteng provincial roads is -R440 million. Figures for different years were used on the cost and effectiveness side respectively, as other figures were not readily available. 


\section{Cost-effectiveness model applied to traffic on Gauteng provincial roads}

The result is shown in Figure 2.

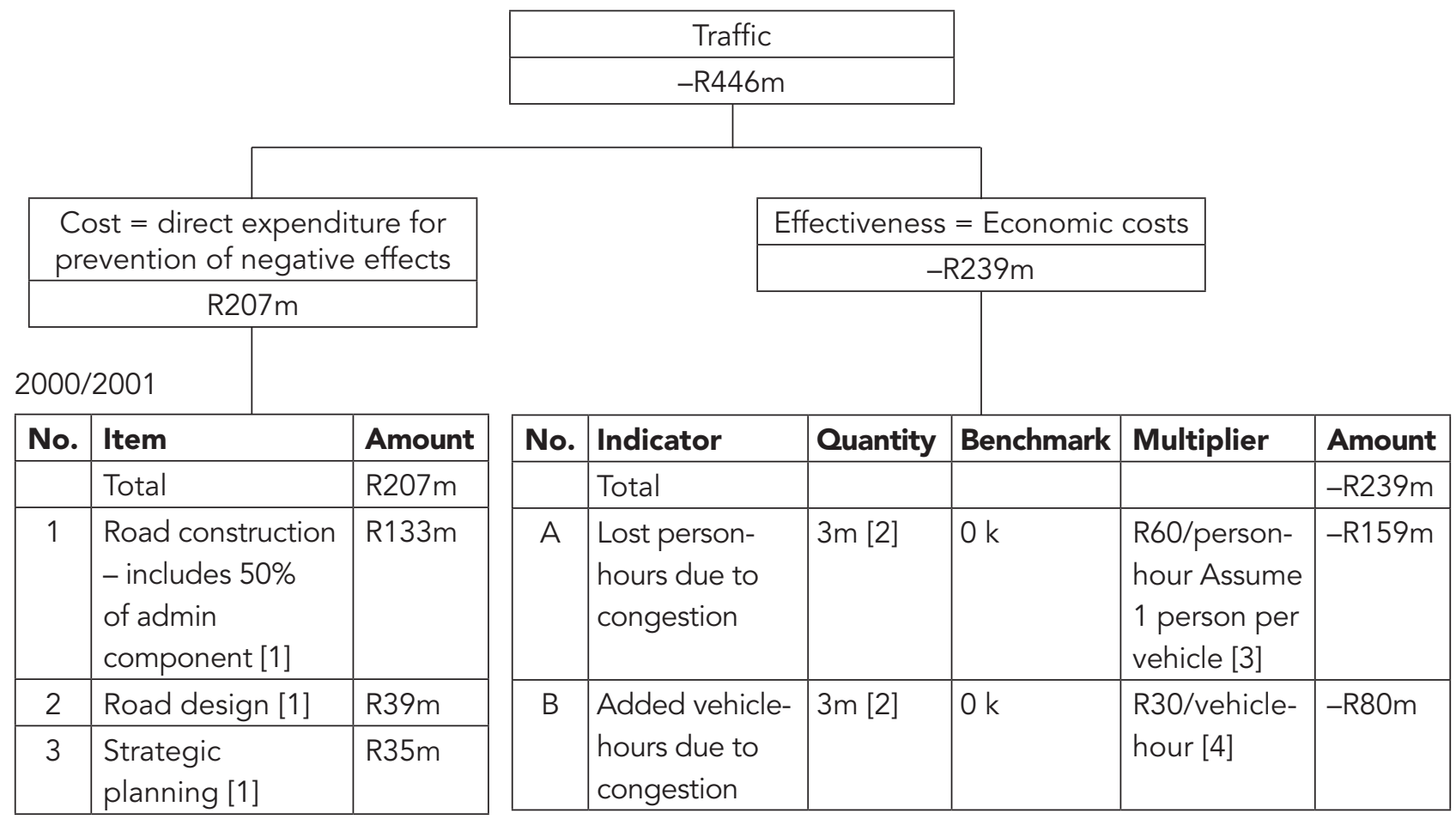

\section{Notes to Figure $\mathbf{2}$ (numbers in square brackets refer to notes below):}

General note: Letter $m$ and $k$ after a number implies million and thousand respectively.

Note 1: Gauteng Department of Public Transport, Roads and Works 2003b: 29 \& 34.

Note 2: Table 1: $(Y \div \mathrm{Z}) \times \mathrm{U} \times \mathrm{T} \times \mathrm{V} \times \mathrm{H} \div \mathrm{Za}$

Note 3: Table 1: L

Note 4: Table 1: M

Figure 2: Cost-effectiveness model applied to traffic on Gauteng provincial roads

Figure 2 shows that, given the indicated assumptions in Table I, the total cost of congestion on Gauteng provincial roads amounts to R239 million (on the effectiveness side). If this is added to the direct provincial expenditure allocated to this function, the total negative contribution of the traffic situation on roads under the jurisdiction of the Gauteng provincial government is R446 million per annum. This is of the same order of magnitude as the equivalent costs of accidents on the same roads. 
Cost-effectiveness model applied to road infrastructure on Gauteng provincial roads The result is shown in Figure 3.

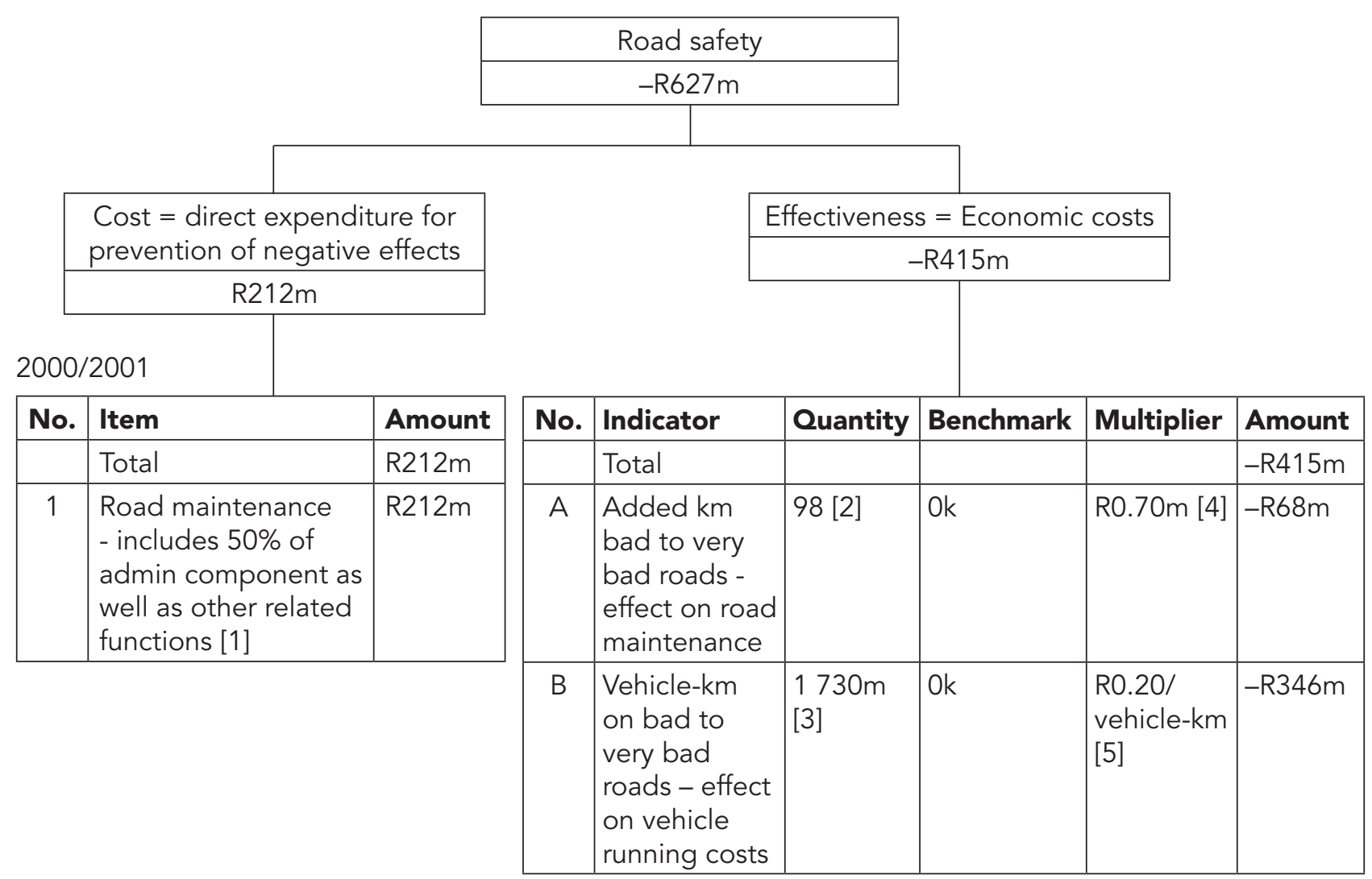

\section{Notes to Figure $\mathbf{3}$ (numbers in square brackets refer to notes below):}

General note: Letter $m$ and $k$ after a number implies million and thousand respectively.

Note 1: Gauteng Department of Public Transport, Roads and Works 2003b: 34.

Note 2: Table 1: $\mathrm{H} \times \mathrm{S}$

Note 3: Table 1: $\mathrm{Y} \times \mathrm{R} \times \mathrm{H} \div \mathrm{Za}$

Note 4: Table 1: A-B rounded.

Note 5: Table 1: F scaled down by the author.

Figure 3: Cost-effectiveness model applied to road infrastructure on Gauteng provincial roads

As before, most of the quantities in Figure 3 were derived from the assumptions in Table I. The visual road condition was obtained from the Gauteng Department of Public Transport, Roads and Works, 2001. The document indicates the percentage of bad to very bad roads on the provincial road network for each year. Vehicle-kilometres for the whole of South Africa were obtained from National Department of Transport, 2001, Table 2.4.13, and proportioned to the number of active vehicles and the percentage provincial road length.

Given the assumptions, the equivalent negative effect of the 'bad' road infrastructure to the economy is R627 million. This is somewhat higher than each of the other two applications discussed above. 


\section{Summary}

In isolation, the amounts in Figures 1,2 and 3 have little meaning. Systems-thinking mandates that the interaction between elements is more important than the elements themselves and that a given system should be investigated within the context of its containing whole (Backeberg, 2005). This can be achieved by normalising the figures in terms of the population and the per capita income (indicators of the 'containing whole' within which the transportation subsystem operates). The result is illustrated in Figure 4.
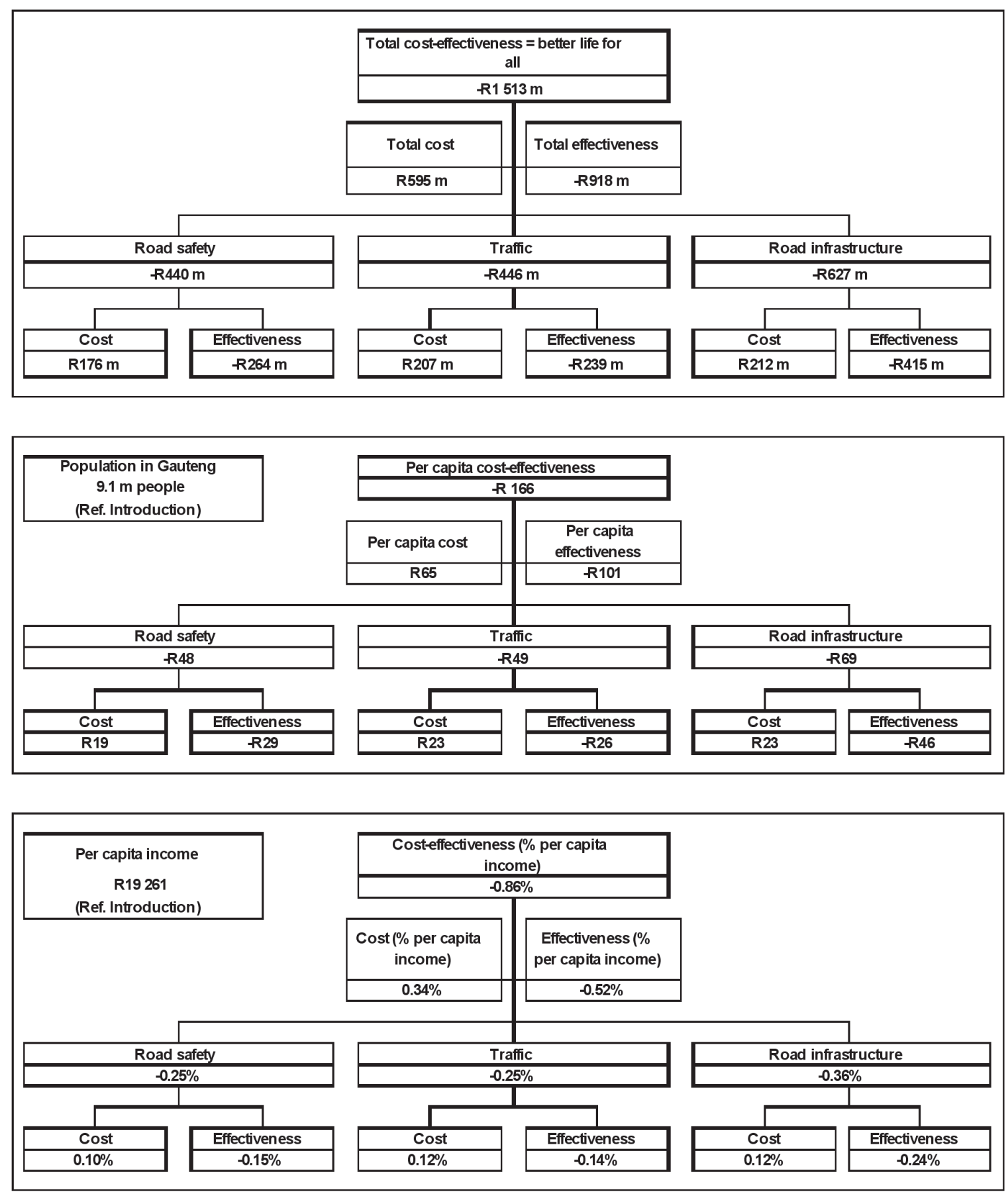

Figure 4: Combined cost-effectiveness model for Gauteng roads under provincial jurisdiction: In absolute terms, per capita and as a percentage of the per capita income 
Figure 4 shows that the 'average person' in Gauteng pays R166 as a result of the ineffectiveness of the roads under provincial administration. This amounts to $0.86 \%$ of his or her annual income. This amount again has little meaning, as the 'average person' does not distinguish between national, provincial and local roads. By scaling the amount up to all roads within the province, a more meaningful figure can be obtained.

The total road network in Gauteng spans $34100 \mathrm{~km}$, of which $4888 \mathrm{~km}$ are under provincial jurisdiction (Gauteng Department of Public Transport, Roads and Works, 2003b: 3.8). The ratio then becomes 34 100/4 $888=7.0$. The result is shown in Figure 5 .
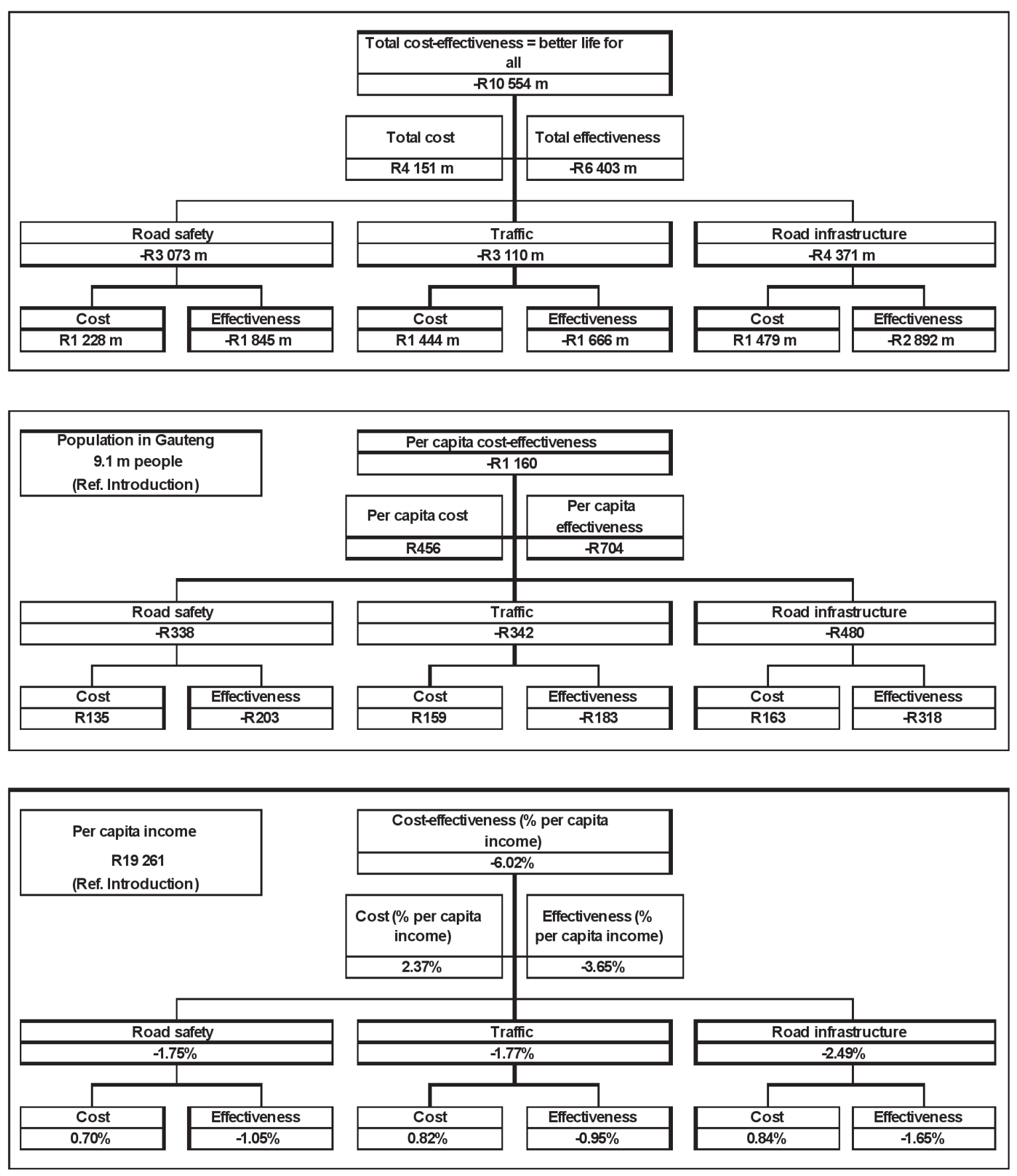

Figure 5: Combined cost-effectiveness model proportioned to all roads within Gauteng: In absolute terms, per capita and as a percentage of the per capita income 
Figure 5 provides an indication of the contribution of transportation within Gauteng towards a better life for all. As many of the values in Figure 4 were scaled down from national and provincial values in the first place, the values in Figure 5 can be regarded as representative for the province as a whole. According to Figure 5, the negative contribution of transportation towards a better life for all in Gauteng is approximately R11 billion per annum. This equates to R1 160 per person per annum, which is about $6 \%$ of the average person's annual income. Such a deduction is not possible without integrated (i.e. links between) information elements, such as per capita income, accident rate, accident severity, congestion severity, etc. This again demonstrates the importance of the links between system elements.

\section{PERFORMANCE OF TRANSPORTATION IN THE CONTEXT OF PAST PERFORMANCE}

Again, the question may be asked whether the above performance is necessarily bad, especially in lieu of the fact that it is based on subjective assumptions. Part of the answer lies in comparison with the past. In the context of systems-thinking, more understanding will result if the quantities are explained in the context of the 'containing whole' within a time dimension. For the purpose of the demonstration, only the effectiveness side (or economic costs) will be illustrated. The result is shown in Figure 6.

\section{Transportation cumulative effectiveness trend}

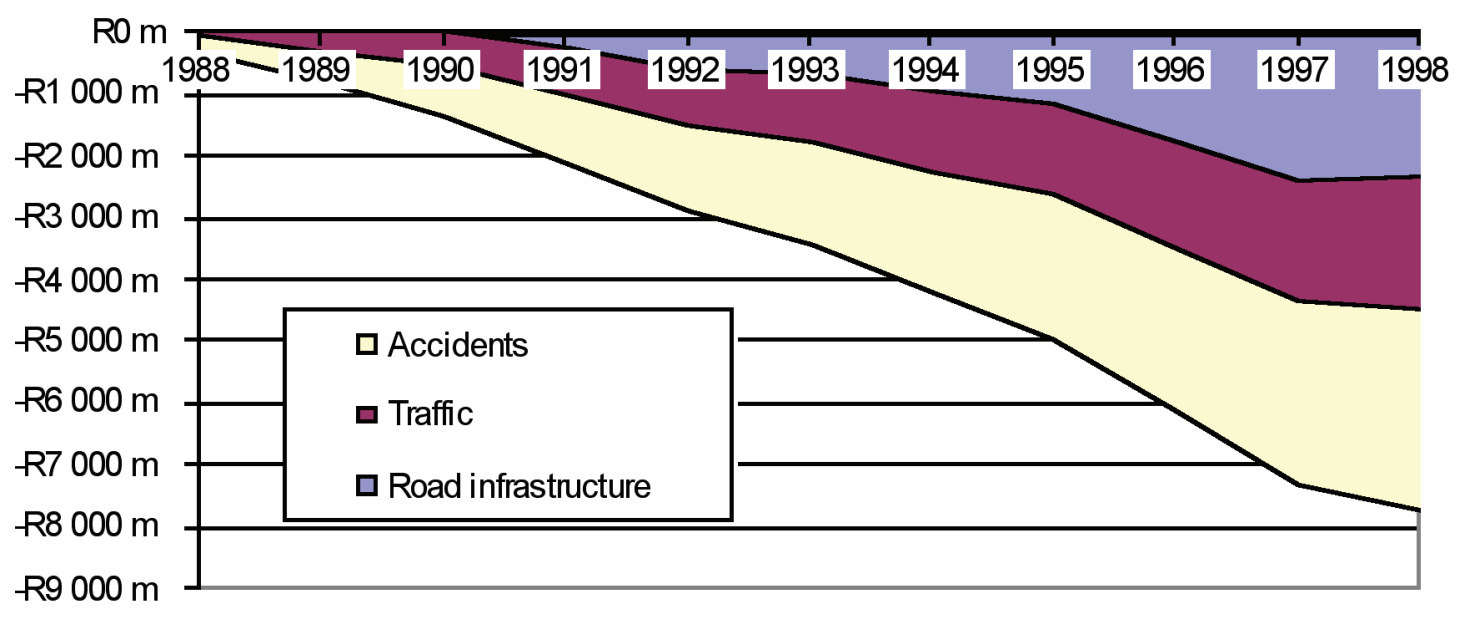

Figure 6: Cumulative economic costs of transportation on Gauteng provincial roads between 1988 and 1998

Figure 6 shows how the economic costs of accidents, congestion and bad road conditions built up between 1988 and 1998. The amounts were obtained as follows:

\section{A. Road safety (measured by the number and severity of accidents)}

The economic costs for each year were calculated as in Figure 1. The human injury statistics for each year for South Africa as a whole were obtained from CSIR, 2002, and proportioned to Gauteng provincial roads. Where information was not readily available, the 1998 ratios in Figure 1 were used. 


\section{B. Traffic (measured by the level of congestion)}

It is generally known that congestion increases each year in Gauteng. An increase in congestion of $2.5 \%$ per annum was assumed (rounded from Arcus Gibb, 2005). The values in Figure 2 were taken as base values.

\section{Road infrastructure (measured by the user cost of bad roads and the additional cost to repair these roads)}

The economic costs for each year were calculated as in Figure 3. The visual road condition was obtained from Gauteng Department of Public Transport, Roads and Works, 2001. The document indicates the percentage of bad to very bad roads on the provincial road network for each year. Vehicle-kilometres in each year for the whole of South Africa were obtained from the National Department of Transport, 2001, Table 2.4.13, and proportioned to the number of active vehicles and percentage provincial road length.

\section{PRIORITISING TRANSPORTATION IMPROVEMENTS}

\section{Introduction}

All the above is still of little value if it does not assist the decision-maker to determine where to improve in order to most optimally arrive at a "better life for all".

\section{Improving congestion and road infrastructure}

Two possible improvements are demonstrated, namely improving congestion on a certain length of the Ben Schoeman highway and repairing a bad road. The calculations are illustrated in Table II.

Table II: Calculation of the potential return on investment on an improvement of a congestion hotspot and an improvement of a bad to very bad stretch of road

\begin{tabular}{|c|l|l|l|}
\hline No & $\begin{array}{l}\text { Ben Schoeman between Olifantsfontein } \\
\text { and New Road }\end{array}$ & $\begin{array}{l}\text { Value } \\
(\mathbf{m}=\mathbf{m i l l i o n})\end{array}$ & Source/Remark \\
\hline A & Average daily traffic in February 2005 & $\begin{array}{l}134252 \\
\text { vehicles }\end{array}$ & Arcus Gibb, 2005 \\
\hline B & Road length & $2.4 \mathrm{~km}$ & Arcus Gibb, 2005 \\
\hline C & Total annual traffic & $\begin{array}{l}29.26 \mathrm{~m} \\
\text { vehicles }\end{array}$ & Arcus Gibb, 2005 \\
\hline D & Average speed at night & $111.3 \mathrm{~km} / \mathrm{h}$ & Arcus Gibb, 2005 \\
\hline E & Average speed & $100 \mathrm{~km} / \mathrm{h}$ & Arcus Gibb, 2005 \\
\hline F & Average time during night per vehicle trip & 0.022 hours & B $\div$ D \\
\hline G & Average time total per vehicle trip & 0.024 hours & B $\div$ E \\
\hline H & Average time lost per vehicle trip & 0.002 hours & G - F - Assume no congestion at night \\
\hline I & Total time lost due to congestion & 71292 hours & $\mathrm{C} \times \mathrm{H}$ \\
\hline J & Total cost per hour & R90 per hour & Table I: L, M and P \\
\hline
\end{tabular}




\begin{tabular}{|c|l|l|l|}
\hline $\mathrm{K}$ & Total cost of congestion over $2.4 \mathrm{~km}$ & $\mathrm{R} 6 \mathrm{~m}$ per year & \\
\hline $\mathrm{L}$ & Cost per additional lane on both sides per $\mathrm{km}$ & $\mathrm{R} 10 \mathrm{~m}$ per $\mathrm{km}$ & Table I: $\mathrm{D}$ \\
\hline $\mathrm{M}$ & Total cost of additional lane on both sides & $\mathrm{R} 24 \mathrm{~m}$ & $\mathrm{~B} \times \mathrm{L}$ \\
\hline $\mathrm{N}$ & Percentage congestion costs solved & $80 \%$ & Assumption \\
\hline $\mathrm{O}$ & Payback period & 4.68 years & $\mathrm{M} \div(\mathrm{K} \times \mathrm{N})$ \\
\hline $\mathrm{P}$ & Road repair costs per $\mathrm{km}$ & $\mathrm{R} 1.4 \mathrm{~m}$ per $\mathrm{km}$ & Table I: $\mathrm{A}$ \\
\hline $\mathrm{O}$ & $\begin{array}{l}\text { Average annual economic costs per } \mathrm{km} \text { of } \\
\text { bad to very bad roads }\end{array}$ & $\mathrm{R} 4.2 \mathrm{~m}$ per $\mathrm{km}$ & $\mathrm{R} 415 \mathrm{~m} / 98 \mathrm{~km}$. Calculated from Figure 3 \\
\hline $\mathrm{R}$ & Payback period & 0.3 year & $\mathrm{P} \div \mathrm{Q}-$ based on equal road use \\
\hline
\end{tabular}

Table II demonstrates the value of adequate information by means of the Ben Schoeman highway between Pretoria and Johannesburg as an example. This highway is known for its increased congestion levels over the past 10 years (Arcus Gibb, 2005). The table takes the reader through the relevant calculations and is self-explanatory. The value of improving this congestion hotspot can be compared with the cost of repairing bad to very bad roads. Given the listed assumptions, the payback period for solving the congestion is more than ten times higher than the payback period for repairing the bad roads. Although the answer is by no means conclusive, it may warrant further investigation.

The above figures can be compared with the Gautrain rapid rail link between Johannesburg and Pretoria (Kruger, 2005). At an assumed capital cost of R8 billion, for a total length of 80 $\mathrm{km}$, the cost per kilometre is R100 million. With this money, one intersection per kilometre plus five additional lanes on each side can be built (Table I: D \& E). According to Arcus Gibb (2005) the average daily traffic (per working day) on the said $2.4 \mathrm{~km}$ stretch (summed for both directions) is 134252 vehicles. If the average vehicle occupancy is estimated at 2 people per vehicle, the number of people trips can be estimated at 270000 (rounded). Kruger (2005) quotes Shilowa as saying that trains will run every 10-15 minutes, and will transport 104000 people every day. This equates to 52000 vehicles, which is about $40 \%$ of the traffic on the Ben Schoeman highway.

In Table II (K) it was estimated that the annual cost of congestion over $2.4 \mathrm{~km}$ is R6 million. If (as a worst case) this figure is doubled to make provision for losses at off- and onramps, the average annual cost per $\mathrm{km}$ road length is R5 $\mathrm{m}$. At a capital cost of R100 million per $\mathrm{km}$, the payback period for the Gautrain is 20 years. This is about four times the payback period for widening the Ben Schoeman highway and about 60 times the payback period for repairing bad roads.

This analysis is for demonstration only, and excludes important variables such as the running costs and safety of the high speed train relative to other options. It demonstrates however the importance of having adequate and quantifiable statistics in a comparable format at hand for prioritising improvements. 


\section{Reducing the accident rate}

In the following example, the 'high' accident rate will be addressed. This can be done in various dimensions, e.g. geographical or by user group. As the previous analysis was based on a geographical dimension, the next example will be done by user group. The author investigated the accident statistics of various user groups and found that minibus taxis had a higher rate than average. These statistics, together with those statistics for the total vehicle population, are shown in Table III.

Table III: Extract of accident statistics by user group (numbers in square brackets refer to notes at the bottom)

\begin{tabular}{|c|c|c|c|c|}
\hline No & Description & South Africa [1] & Gauteng & $\begin{array}{l}\text { Gauteng provincial } \\
\text { roads }(3)\end{array}$ \\
\hline \multicolumn{5}{|c|}{ All vehicles - 1998} \\
\hline A & Registered vehicles & 6349453 & 2450 [1] & 351225 \\
\hline $\mathrm{B}$ & Distance covered (million km) & 130137 & $50220[2]$ & 7199 \\
\hline $\mathrm{C}$ & Vehicles involved in accidents & 866536 & 334394 [2] & 47933 \\
\hline $\mathrm{D}$ & Accidents & 511605 & 197427 [2] & 28300 \\
\hline$E$ & Fatalities & 9068 & $3499[2]$ & 502 \\
\hline $\mathrm{F}$ & Casualties & 129672 & $50040[2]$ & 7173 \\
\hline G & Vehicles involved per $100 \mathrm{~m}$ vehicle $\mathrm{km}$ & 666 & 666 & 666 \\
\hline $\mathrm{H}$ & Accident rate per $100 \mathrm{~m}$ vehicle $\mathrm{km}$ & 393 & 393 & 393 \\
\hline I & Fatality rate per $100 \mathrm{~m}$ vehicle $\mathrm{km}$ & 7 & 7 & 7 \\
\hline $\mathrm{J}$ & Casualty rate per $100 \mathrm{~m}$ vehicle $\mathrm{km}$ & 100 & 100 & 100 \\
\hline K & Vehicles involved per 10000 vehicles & 1365 & 1365 & 1365 \\
\hline $\mathrm{L}$ & Fatality rate per 10000 vehicles & 14 & 14 & 14 \\
\hline \multirow[t]{2}{*}{ M } & Casualty rate per 10000 vehicles & 204 & 204 & 204 \\
\hline & Minibuses - 1998 & & & \\
\hline $\mathrm{N}$ & Registered minibuses & 254957 & $34940[4]$ & 5008 \\
\hline $\mathrm{O}$ & Distance covered (million km) & 6702 & $918[5]$ & 132 \\
\hline $\mathrm{P}$ & Minibuses involved in accidents & 69710 & $9553[5]$ & 1369 \\
\hline $\mathrm{Q}$ & Fatalities & 1140 & $156[5]$ & 22 \\
\hline $\mathrm{R}$ & Casualties & 18012 & $2468[5]$ & 354 \\
\hline $\mathrm{S}$ & Accident rate per $100 \mathrm{~m}$ vehicle $\mathrm{km}$ & 1040 & 1040 & 1040 \\
\hline $\mathrm{T}$ & Fatality rate per $100 \mathrm{~m}$ vehicle $\mathrm{km}$ & 17 & 17 & 17 \\
\hline $\mathrm{U}$ & Casualty rate per $100 \mathrm{~m}$ vehicle $\mathrm{km}$ & 269 & 269 & 269 \\
\hline $\mathrm{V}$ & Minibuses involved as percentage & $27.30 \%$ & $27 \%$ & $27 \%$ \\
\hline W & Minibuses involved per 10000 minibuses & 2734 & 2734 & 2734 \\
\hline$x$ & Fatality rate per 10000 minibuses & 45 & 45 & 45 \\
\hline \multirow[t]{2}{*}{$\mathrm{Y}$} & Casualty rate per 10000 minibuses & 706 & 706 & 706 \\
\hline & \multicolumn{4}{|c|}{$\begin{array}{l}\text { Notes: } \\
\text { 1. National Department of Transport, 2001, Table } 2.4 .13 \text {. } \\
\text { 2. Proportioned to A. } \\
\text { 3. Proportioned to road length where applicable }(H \div Z \text { a in Table } 1=1 \div 7) \text {. } \\
\text { 4. Gauteng Department of Public Transport, Roads and Works 2003a: 3.7. } \\
\text { 5. Proportioned to N. }\end{array}$} \\
\hline
\end{tabular}


Table III indicates that taxis have a significantly higher fatality rate per vehicle-kilometre than the average rate for all the vehicles. With the latter as benchmark, the potential savings are populated into the effectiveness side of the cost-effectiveness model, similar to Figure 1. This is shown in Figure 7.

\begin{tabular}{|c|c|c|c|c|c|}
\hline & \multirow{2}{*}{\multicolumn{2}{|c|}{ Effectiveness (inverse) = Cost of effect to economy }} & & \\
\hline & & & & & \\
\hline & & \multicolumn{2}{|c|}{$-\mathrm{R} 62 \mathrm{~m}$} & & \\
\hline \multirow[t]{2}{*}{ No. } & Indicator & Quantity & Benchmark & Multiplier & Amount \\
\hline & Total & & & & $-\mathrm{R} 62 \mathrm{~m}$ \\
\hline A & Fatalities & 22 & 9 & R500k & $-\mathrm{R} 6 \mathrm{~m}$ \\
\hline B & $\begin{array}{l}\text { Seriously } \\
\text { injured }\end{array}$ & 141 & 58 & R100k & $-\mathrm{R} 8 \mathrm{~m}$ \\
\hline C & Slightly injured & 1786 & 735 & R30k & $-\mathrm{R} 32 \mathrm{~m}$ \\
\hline \multirow[t]{2}{*}{$\mathrm{D}$} & Damage only & 1369 & 564 & R20k & $-\mathrm{R} 16 \mathrm{~m}$ \\
\hline & Assumptions: & $\begin{array}{l}\text { A: National Department of } \\
\text { Transport, 2001, Table 2.4.13. } \\
\text { B,C: Same ratio to fatalities as in } \\
\text { Figure } 1 . \\
\text { D: Vehicles involved in accidents. }\end{array}$ & $\begin{array}{l}\text { A: Proportioned to } \\
\text { fatalities per } 100000 \\
\mathrm{~km} \text { for all vehicles. } \\
\text { B, C, D: Same ratio } \\
\text { as fatalities. }\end{array}$ & & \\
\hline
\end{tabular}

Figure 7: Total annual economic costs of taxi accident relative to overall accident rate scaled down to Gauteng provincial roads

Figure 7 indicates that taxi accidents (proportioned to the road length under administration of the Gauteng provincial government) cost R62 million in a specific year. This is a fictitious amount, as taxis are not limited to any of the national, provincial or local roads. The amount is however important for comparisons with the direct expenditure of the Gauteng Provincial Government (see Figure 1). The amount makes more general sense, when normalising it per taxi vehicle, as shown in Figure 8. 


\begin{tabular}{|c|}
\hline Effectiveness (inverse) $=$ Cost of effect to economy per taxi \\
\hline- R12.5k
\end{tabular}

Taxi 5008 units as proportioned to provincial roads

\begin{tabular}{|c|l|l|l|l|l|}
\hline No. & Indicator & Quantity & Benchmark & Multiplier & Amount \\
\hline & Total & & & & $-\mathrm{R} 12.5 \mathrm{k}$ \\
\hline A & Fatalities & 0.0044 & 0.0018 & R500k & $-\mathrm{R} 1.3 \mathrm{k}$ \\
\hline B & $\begin{array}{l}\text { Seriously } \\
\text { injured }\end{array}$ & 0.0282 & 0.0116 & R100k & $-\mathrm{R} 1.7 \mathrm{k}$ \\
\hline C & Slightly injured & 0.3566 & 0.1468 & R30k & - R6.3k \\
\hline D & Damage only & 0.2734 & 0.1126 & R20k & - R3.2k \\
\hline & Assumptions: & $\begin{array}{l}\text { A: National Department of } \\
\text { Transport, 2001, Table 2.4.13. } \\
\text { B,C: Same ratio to fatalities as in } \\
\text { Figure 1. } \\
\text { D: Vehicles involved in accidents. }\end{array}$ & $\begin{array}{l}\text { A: Proportioned to } \\
\text { fatalities per 100 000 } \\
\text { km for all vehicles. } \\
\text { B, C, D: Same ratio } \\
\text { as fatalities. }\end{array}$ & & \\
\hline
\end{tabular}

Figure 8: Annual economic costs per taxi of taxi accident rate relative to accident rate for all vehicles

Figure 8 shows that, on average, each taxi costs the economy R12 500 per annum because of the higher than average accident rate. This can be compared to the taxi recapitalisation costs. If the investment of the government is R50 000 per taxi (National government of South Africa - Parliamentary monitoring group, 2004), the payback period is about 4 years, under the following assumptions:

- The main reason for the recapitalisation is safety.

- All other costs (per passenger-trip) remain the same after recapitalisation.

- The recapitalisation programme will bring the taxi accidents on a par with the average accident rate in the country/province. This is questionable.

\section{IMPLICATIONS FOR DECISION-MAKERS AND BENEFICIARIES}

The study shows that it is only such integrated, quantified and linked information that makes it possible for decision-makers to prioritise their budgets between different functions such as road maintenance, congestion elimination and driver education, to mention only a few. The result of the study indicates that about $6 \%$ of South Africa's per capita income is lost to suboptimal transportation, of which about $2.5 \%$ can be attributed to bad road surfaces. Any capital expenditure on the latter will be paid back to the average taxpayer in less than a year. 
Traditionally, decision-makers and their beneficiaries did not have integrated information as illustrated above. With such information now at hand, decision-makers are able to optimise their budgets and justify their actions. Furthermore, both decision-makers and beneficiaries will understand the reasoning behind these actions and be able measure to what extent the advantages realised at the end, in terms of evaluation, corrective action and improvement.

\section{SUMMARY}

The research started by populating the cost-effectiveness framework with transportation information from various sources. It was shown that the contribution of transportation to a "better life for all" could be calculated in this way. However, the necessary information had to be extracted from diverse sources and many assumptions, extrapolations and approximations had to be made.

The above statistics were then made more meaningful by putting them into the context of past statistics, by means of a trend graph. Indications are that the contribution of transportation towards a better life for all worsened in the past ten years. Again, accurate information was difficult (if not impossible) to obtain.

Lastly, an attempt was made to demonstrate how improvements could be prioritised if adequate information was available. Four corrective actions were investigated:

- repairing the worst roads

- solving one of the worst congestion hotspots by means of extra lanes

- solving one of the worst congestion hotspots by means of a high-speed train

- focusing on the user group with the worst accident rate in order to reduce accidents.

According to the assumptions and approximations, repair of bad roads added the most value per unit expenditure and a high-speed train (to alleviate congestion) the least. It was shown that adequate information could identify the user group where improvements would have the highest return (e.g. the highest effect on reducing the accident rate).

In all the above instances, normalising statistics such as number of vehicle-kilometres, number of passengers and road lengths were of utmost importance for proper comparison and interpretation - or, in systems terms, proper understanding (Backeberg, 2005). 


\section{CONCLUSION}

A cost-effectiveness framework populated by adequate, timely, integrated information makes informed decision-making possible up to the highest level. This is currently not possible, as there is a lack of such information.

To make the above possible, an integrated transportation data acquisitioning and reporting system is needed. It is recommended that an affordable data acquisitioning system be developed and implemented. The conceptualisation of such a system is recommended for further research.

\section{ACKNOWLEDGEMENTS}

This paper is based on research within the Gauteng Department of Public Transport, Roads and Words, which eventually led to a transportation surveying strategy, completed in 2004 (Arcus Gibb, 2004). 


\section{REFERENCES}

Africon. 2003. ITS pilot project: Benefit/cost analysis. Feedback in the form of a PowerPoint presentation by $\mathrm{J}$ Anderson to the National Road Agency on the Intelligent Transport System pilot project on the Ben Schoeman highway. Pretoria. July.

Africon. 2005. E-mail correspondence by J Victor quantifying road repair costs versus road conditions. 7 July.

Arcus Gibb. 2004. Traffic surveying strategy for the Gauteng Provincial Government. Report number J23104A100/01. Study directed by Arcus Gibb under sponsorship of the Gauteng Department of Public Transport Roads and Works. January.

Arcus Gibb. 2005. Information supplied by J de Bruyn from Arcus Gibb on 5 August 2005.

Backeberg, G.H. 2005. A systems approach to transportation surveying in Gauteng, South Africa. Southern African Business Review, 9(1): 21-31. April.

CSIR Division of Roads and Transport Technology: Schutte, I.C. 2000. An estimate of the unit cost of road traffic collisions in South Africa for 1998. Report no. CR-2000/4, submitted March 2000 to National Department of Transport, Pretoria.

CSIR. 2002. Summary Table: Accidents and casualties according to degree, 1998. Available: http://www.roadsafetycafe.co.za/Statistics. Consulted 5 July 2005.

Gauteng Department of Public Transport, Roads and Works. 2001. Annual Report 2000/1. Available: http://www.gpg.gov.za/docs/reports/annuals01/plans.html. Consulted 27 June 2005.

Gauteng Department of Public Transport, Roads and Works 2002. Annual Report. Johannesburg.

Gauteng Department of Public Transport, Roads and Works. 2003a. Provincial land transport framework for Gauteng, 2002-2007, Johannesburg. January.

Gauteng Department of Public Transport, Roads and Works. 2003b. Strategic plan 20032006, Johannesburg. 11 March.

Katz, D. 2005. An Unwarranted attack on SUVs. 11 March. Available: http://www. washingtonpolicy.org/Misc/PNKatzSUV2003-11.html. Consulted: 6 August 2005. 
Kruger, E. 2005. Gautrein verlaateperron. Rekord, 14 July 2005. Available: www.rekord .co. za. Consulted 15 July 2005.

National Department of Transport 2001: Transport Statistics 2001, Part II. Available: http:// www.transport.gov.za. Consulted 13 July 2005.

National Government of South Africa 1999: Public Finance Management Act, Act No. 1 of 1999 as amended by Public Finance Management Amendment Act, No. 29 of 1999. Government Gazette. No. 19814. 2 March 1999. Cape Town.

National Government of South Africa - Parliamentary monitoring group. 2004. Government statement on the taxi recapitalisation project, 4 November 2004. Available at: http://www. pmg.org.za/briefings. Consulted: 23 September 2005. 